\title{
Industrial hemp for biomass production
}

\author{
R. Sausserde, A. Adamovics \\ Latvia University of Agriculture, Institute of Agrobiotechnology, Republic of Latvia
}

\begin{abstract}
Interest for possibilities of the industrial hemp (Cannabis sativa L.) growing in Latvia is increasing year by year and they are considered as one of the most promising renewable biomass sources to replace nonrenewable natural resources for manufacturing of wide range industrial products. The aim of this research was to evaluate of biomass potential of some industrial hemp varieties to be recommended to grow in Latvia and clarify carbon content. The biometric parameters of ten industrial hemp cultivars - 'Bialobrzeskie', 'Futura 75', 'Fedora 17', 'Santhica 27', 'Beniko', 'Ferimon', 'Epsilon 68', 'Tygra', 'Wojko' and 'Uso 31' have been investigated at the Research and Study farm "Peterlauki" of the Latvia University of Agriculture in 2011-2012. The carbon content was determined. The results of investigation show that industrial hemp is promising plant for biomass production in Latvia. Depending on the variety the green over-ground biomass varies from 36 - $54 \mathrm{t} \mathrm{ha}^{-1}$ in 2011 and from 48 - $75 \mathrm{t} \mathrm{ha}^{-1}$ in 2012 . The highest green over-ground biomass was obtained cultivar 'Futura 75 ' up to $75 \mathrm{t} \mathrm{ha}^{-1}$. The carbon content in hemp stems was found from $41.62-45.38 \%$ and it depend on cultivars. Results of investigation of biomass potential of all ten industrial hemp cultivars are presented.
\end{abstract}

\section{Introduction}

The industrial hemp (Cannabis sativa L.) is one of the earliest domesticated and widespread crop all over the world. For many centuries hemp has been cultivated as a source of strong stem fibre and seed oil in Latvia (Ehrensing, 1998). In the 19th century the cultivation of industrial hemp in Europe declined but recently interest has been renewed, for example in Germany, France, the Netherland, the United Kingdom, Spain and Italy, but also elsewhere in the world

Correspondence: Rudite Sausserde, Latvia University of Agriculture, Institute of Agrobiotechnology, Republic of Latvia.

E-mail: ruditei@inbox.lv

Key words: hemp, cannabis sativa, ash, carbon

Acknowledgments: the research was supported by the European Regional Development Fund, Agreement No. 2010/0320/2DP/2.1.1.1.0/10/APIA/VIAA/107.

(C) Copyright R. Sausserde and A. Adamovics, 2013

Licensee PAGEPress, Italy

Journal of Agricultural Engineering 2013; XLIV(s2):e123

doi:10.4081/jae.2013.s2.e123

This article is distributed under the terms of the Creative Commons Attribution Noncommercial License (by-nc 3.0) which permits any noncommercial use, distribution, and reproduction in any medium, provided the original author(s) and source are credited.
(Struik et al., 2000). And nowadays industrial hemp has become very important as a crop for biomass production. Environmental concern and recent shortages of wood fibre have renewed interesting hemp as a raw material for a wide range of industrial products including textiles, paper, and composite wood products (Ehrensing, 1998).

It is fast-growing and suitable for Latvia's agro-climate conditions. Latvian hemp sowing areas are registered only in year 2008 and in year 2009 was grown 250 ha. In recent years, the amount of industrial hemp growers and cultivated areas has increased in Latvia and, according to data provided by Association of Industrial Hemp of Latvia, plantations area of hemps is approximately 600 ha in Latvia in 2012. And it means that, interest for possibilities of the hemp growing in Latvia is increasing year by year. And they are considered as one of the most promising renewable biomass sources because it contains the energy which comes from the sun (Adamovi $\square$ s et al., 2012). Through the process of photosynthesis, chlorophyll present in plants absorbs the energy from the sun by converting the carbon-dioxide present in air and water from the ground in carbohydrates.

In Latvia industrial hemp is legally allowed to be grown but the main requirement is that hemp plants should have a low THC (Tetrahydrocannabiol) content (less than 0.2\%). The EU common catalogue of varieties of agricultural plant species contains the list with more than 47 industrial hemp varieties (Cannabis sativa..., 2009). And it is diffi cult to decide which variety from this list could be possible to grow in Latvia with good results and with high biomass yield. The aim of this research was to evaluate of biomass potential of some industrial hemp varieties to be recommended to grow in Latvia and clarify carbon content.

\section{Material and methods}

The field trial was carried out in 2011 - 2012 in Research and Study farm "Peterlauki" $\left(56^{\circ} 53^{\prime} \mathrm{N}, 23^{\circ} 71^{\prime} \mathrm{E}\right)$ of the Latvia University of Agriculture, in the sod calcareous soils pHKCl 6.7, containing available for plants P $52 \mathrm{mg} \mathrm{kg} \square 1$, K $128 \mathrm{mg} \mathrm{kg} \square 1$, organic matter content 21 to $25 \mathrm{~g} \mathrm{~kg} \square 1$ in the soil.

There were ten industrial hemp cultivars tested - 'Bialobrzeskie', 'Futura 75', 'Fedora 17', 'Santhica 27', 'Beniko', 'Ferimon', 'Epsilon 68', 'Tygra', 'Wojko' and 'Uso 31'.

Hemp sowing was made by Wintersteiger plot sowing machine in the middle of May. The trial was randomly spaced, triplicate. The plot size $7 \mathrm{~m} 2$. Fertilizer application rate $-\mathrm{N} 120 \mathrm{P} 80 \mathrm{~K} 112 \mathrm{~kg} \mathrm{ha}^{-1}$. Seed rate $50 \mathrm{~kg} \mathrm{ha}^{-1}$ or average 250 germinate able seeds per $1 \mathrm{~m} 2$. In the field rotation, industrial hemp followed previous crop - spring barley. Hemp was harvested by a small mower MF-70 (leaving the stubble of $5-8 \mathrm{~cm}$ ) when the first matured seed appeared.

During both growing seasons the industrial hemp stalk was estimated. Total height of hemp stalk was measured from the soil surface to the tip of plant. No pesticides like insecticides, herbicides, desiccants were used.

The yield of green and dry biomass was evaluated at hemp harvesting time. The main task of research presented here was to evaluate 


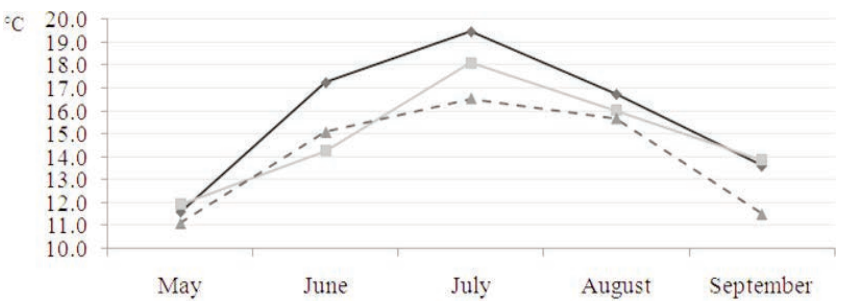

Figure 1. Average temperature during the growing season, 2011-2012 and long-term average $\left({ }^{\circ} \mathrm{C}\right)$ :
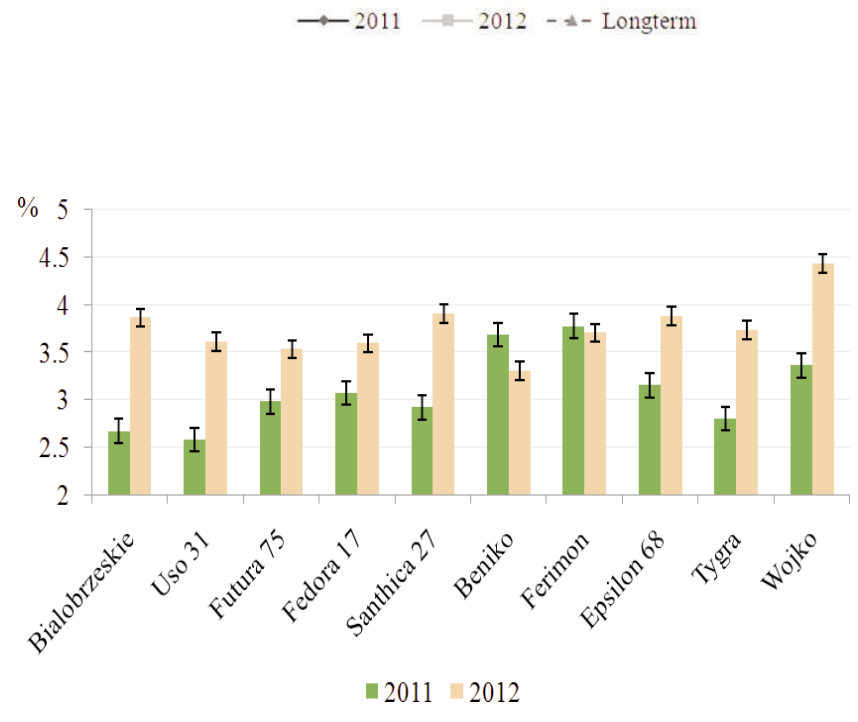

Figure 3. Ash content in hemp of different varieties, \%

biomass potential of ten industrial hemp cultivars under Latvian climatic conditions. The yield of absolutely dry hemp biomass was calculated according to the data of green biomass and its moisture content at harvesting in study years. The carbon content in hemp stem was determined by carbon analyzer Eltra CS-500, which operates on the principles of chromatography. The ash content in hemp stem was determined by a standard method for the rapid ash production method ISO 5984:2002.

Meteorological data as temperature was obtained from Dobele Hydro-meteorological Station (HMS). Precipitations were taken during growing season near to the trials fields in farm Peterlauki. Meteorological conditions during both growing season can be describ ed as good with temperature (Fig. 1) and wet with periodic substantial rainfall (Fig. 2) what was good for hemp growth and development.

A statistical evaluation of the data has been made by ANOVA, variance analysis, the LSD test. Correlation and regression analysis methods were used for data processing.

\section{Results and discussion}

Industrial hemp cultivars growth and development is dependent of meteorological conditions during growing period (Struik et al., 2000). Hemp grows best when mean daily temperatures are between $14{ }^{\circ} \mathrm{C}$ and $27{ }^{\circ} \mathrm{C}$ and it requires abundant moisture throughout the growing season, particularly while young plants are becoming established dur-

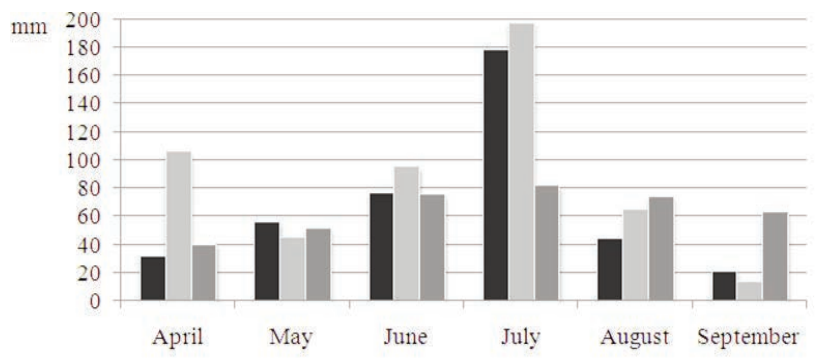

Figure 2. Precipitations during growing season in $2011-2012$ and long-term (mm): - $2011=2012=$ longterm, $\mathrm{mm}$

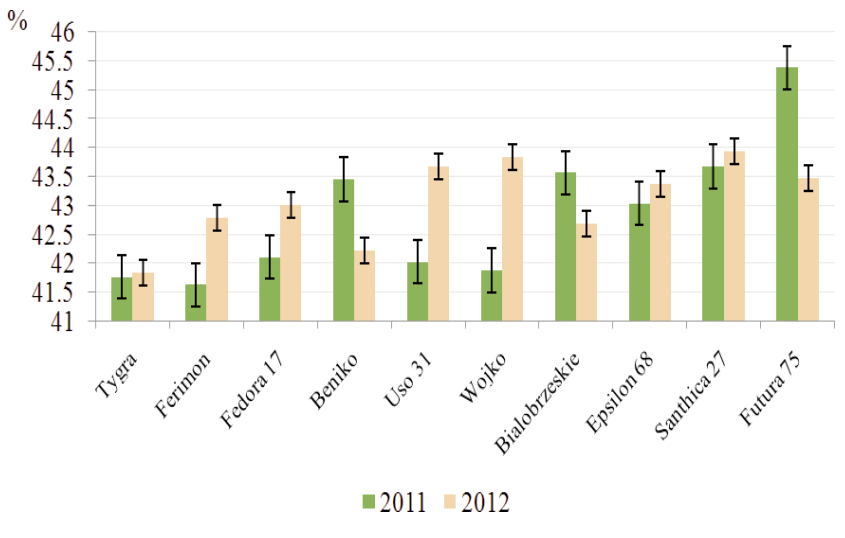

Figure 4. Carbon content in hemp of different varieties, \%

ing the first six weeks of growth (Ehrensing, 1998). According to the data presented in Figure 1 and Figure 2, we can see that meteorological conditions during both trial years were diverse, but both growing seasons were abundant in rainfall which differed only at hemp growing stages and there was good temperature for hemp growth.

According to results, in the years of investigation, the highest stalk length was observed of cultivar 'Bialobrzeskie' $(2.63 \mathrm{~m})$ in 2011 and cultivar 'Tygra' (3.06 m) in 2012 (Tab.1). There were significant difference between different cultivars and growing season. The lowest stalk length was observed of cultivar 'Wojko' (1.95 m) in 2011 and cultivar 'Bialobrzeskie' ( $2.26 \mathrm{~m})$ in 2012.

Statistical evaluation showed that the meteorological conditions during growing season as a factor had an influence on the results of total hemp stalk length.

In 2011, industrial hemp cultivars produced sufficiently high amount of green biomass (Tab.2). Cultivars 'Epsilon 68' and 'Beniko' produced significantly $(\mathrm{p}<0.05)$ higher amount of green biomass (up to $50 \mathrm{t} \mathrm{ha}^{-1}$ ) than the other cultivars tested. But in 2012, the green biomass was obtained higher. In this growing season the significantly higher amount of green biomass was obtained cultivar 'Futura 75' (75 t ha $\left.{ }^{-1}\right)$. The lowest green biomass yield was obtained cultivar 'Uso 31' in 2011.

According to the data of industrial hemp green biomass and amount of plant moisture content at harvesting (it was about 19-45 \% in both trial years), the hemp dry biomass yield was calculated. There was significant difference of dry biomass yield between different cultivars in both years. The significantly highest amount of dry biomass yield up to $20 \mathrm{t} \mathrm{ha}^{-1}$ was observed from cultivars 'Futura 75 ' (21.22 $\left.\mathrm{t} \mathrm{ha}^{-1}\right)$, 
'Beniko' (20.51 t ha-1), 'Wojko' (20.33 t ha-1) and 'Epsilon 68' (20.26 t $\mathrm{ha}^{-1}$ ) but the lowest - cultivar 'Uso 31' (12.65 t ha-1). In 2012, the significantly highest amount of dry biomass yield was observed from cultivars 'Futura 75' (21.33 $\left.\mathrm{t} \mathrm{ha}^{-1}\right)$ and 'Tygra' $\left(20.87 \mathrm{t} \mathrm{ha}^{-1}\right)$ but the lowest from cultivar 'Bialobrzeskie' (11.95 $\left.\mathrm{t} \mathrm{ha}^{-1}\right)$. Statistical evaluation showed that the meteorological conditions during growing season as a factor had an influence on the results of total green and dry biomass yield.

The ash content is one of the major qualitative characteristics of biomass. The ash content of all plant sheave must be up to $3 \%$. The ash content should not surpass 5-7\% under the conditions of correct stockpile. Nevertheless, the experience shows that the ash content can reach even 20\% (Komlajeva et al., 2012). The ash content of hemp cultivars was different and ranged from 2.58 to $3.77 \%$ (Fig.3).

Table 1. Stalk length of industrial hemp varieties

\begin{tabular}{lccc} 
Varieties & \multicolumn{3}{c}{$\begin{array}{c}\text { Plant stalk length, m } \\
\text { 2012 }\end{array}$} \\
Bialobrzeskie & 2.63 & 2.26 & 2.44 \\
Futura 75 & 2.54 & 2.48 & 2.51 \\
\hline Fedora 17 & 2.47 & 2.59 & 2.53 \\
Santhica 27 & 2.52 & 2.66 & 2.59 \\
\hline Beniko & 2.52 & 2.84 & 2.68 \\
Ferimon & 2.41 & 2.84 & 2.63 \\
\hline Epsilon 68 & 2.50 & 2.88 & 2.69 \\
Tygra & 2.49 & 3.06 & 2.78 \\
\hline Wojko & 1.95 & 2.83 & 2.39 \\
Uso 31 & 2.32 & 2.58 & 2.45 \\
\hline Average & 2.44 & 2.70 & 2.57 \\
\hline
\end{tabular}

$\mathrm{LDS}_{0.05}$ variety $=0.21 ; \mathrm{LDS}_{0.05}$ year $=0.09 ; \mathrm{LDS}_{0.05 \text { initeraction between arately ynd year }}=0.29$
Carbon is one of the most important products of photosynthesis for biomass production and it is the primary fuel burning element. It has a high caloric value and this accounts for most of the burnt mass (Cars, 2008). According to the research results, there were seen that the carbon content in hemp stems varies from $41.62-45.38 \%$ in 2011 and from $41.332-43.94 \%$ in 2012 and it depend on cultivars.

\section{Conclusions}

The trial carried out in 2011 - 2012 enables that industrial hemp cultivars tested 'Bialobrzeskie', 'Futura 75', 'Fedora 17', 'Santhica 27', 'Beniko', 'Ferimon', 'Epsilon 68', 'Tygra', 'Wojko' and 'Uso 31' could be successfully grown in Latvia for biomass production. But the highest biomass yield, during both trial years, was obtained from cultivar 'Futura 75'. According to the data we can conclude that the growing season and the selected industrial hemp variety had a significant $(\mathrm{p}<0.05)$ effect on hemp yield.

According to the results, the ash content was significantly $(\mathrm{p}<0.05)$ affected by different meteorological conditions during the growing season, but not affected ( $p>0.05)$ by the selected cultivar.

According to the research results, there were seen that the carbon content in hemp stem s varies from $41.62-45.38 \%$ in 2011 and from $41.332-43.94 \%$ in 2012 and it depend on cultivars.

\section{References}

1. Adamovičs A., Balodis 0., Bartušēvičs J., Gaile Z., Komlajeva L,., Poiša L., Slepitis J., Straume I., Strikauska S., Višinskis Z. 2012. Enerğētisko augu audzēšanas un izmantošanas tehnoloǵijas (Technologies of production and use of production and use of energy crops). In: Atjaunojamā enerǵija un tās efektīva izmantošana

Table 2. Biomass yield of industrial hemp varieties, $2011-2012$

\begin{tabular}{|c|c|c|c|c|c|c|}
\hline \multirow[b]{2}{*}{ Varieties } & \multicolumn{3}{|c|}{ Green biomass, $\mathrm{t} \mathrm{ha}^{-1}$} & \multicolumn{3}{|c|}{ Dry biomass, $\mathrm{t} \mathrm{ha}^{-1}$} \\
\hline & 2011 & 2012 & Average & 2011 & 2012 & Average \\
\hline Bialobrzeskie & 45.80 & 51.25 & 48.53 & 17.15 & 11.95 & 14.55 \\
\hline Futura 75 & 54.56 & 75.00 & 64.78 & 21.22 & 21.33 & 21.27 \\
\hline Fedora 17 & 45.69 & 57.54 & 51.61 & 16.60 & 18.23 & 17.42 \\
\hline Santhica 27 & 47.16 & 66.43 & 56.79 & 19.84 & 17.39 & 18.61 \\
\hline Beniko & 50.21 & 48.97 & 49.59 & 20.51 & 19.27 & 19.89 \\
\hline Ferimon & 46.69 & 52.40 & 49.55 & 16.90 & 18.59 & 17.75 \\
\hline Epsilon 68 & 54.13 & 68.45 & 61.29 & 20.26 & 12.89 & 16.57 \\
\hline Tygra & 44.80 & 58.83 & 51.82 & 18.61 & 20.87 & 19.74 \\
\hline Wojko & 47.15 & 59.48 & 53.32 & 20.33 & 19.91 & 20.12 \\
\hline Uso 31 & 36.57 & 51.49 & 44.03 & 12.65 & 17.38 & 15.01 \\
\hline Average & 47.28 & 58.98 & 53.13 & 18.41 & 17.78 & 18.09 \\
\hline $\mathrm{LDS}_{0.05 \text { variety }}$ & & 10.24 & & & 3.45 & \\
\hline $\mathrm{LDS}_{0.05 \text { year }}$ & & 4.58 & & & 1.54 & \\
\hline $\mathrm{LDS}_{0.05 \text { interaction between variety and year }}$ & & 14.49 & & & 4.88 & \\
\hline$\eta 2 \%_{\text {variety }}$ (impact rate) & & $26.7(\mathrm{p}<0$ & & & $3(\mathrm{p}<0$ & \\
\hline$\eta 2 \%_{\text {year }}$ (impact rate) & & $26.2(p<0$ & & & $9(\mathrm{p}<0$ & \\
\hline$\eta 2 \%$ interaction between year and variety (impact rate) & & $7.6(p>0$. & & & $8(p>0$ & \\
\hline
\end{tabular}


Latvijā (Renewable energy and its effective use in Latvia), Jelgava, pp 88 - 91. (in Latvian).

2. Cannabis sativa L. Hemp. 2009. p 199 - 200. Available at: http://eurlex.europa.eu, 21 April, 2013.

3. Cars, A. 2008. Energoresursi (Energy resources). SIA Baltic Communication Partners, p 102 (in Latvian).

4. Ehrensing D.T. 1998. Feasibility of Industrial Hemp Production in the United States Pacific Northwest. Oregon State Universit. Available at: www.extension.oregonstate.edu/catalog/html/sb/ sb681/, 2 April, 2013.

5. Komlajeva L., Adamovics A., Poisa L. 2012. Comparison of different energy crops for solid fuel production in Latvia. Renewable Energy and Energy efficiency, Growing and processing technologies of energy crops. pp $45-50$.

6. Struik P.C., Amaducci S., Bullard M.J., Stutterheim N.C., Venturi G., Cromack H.T.H. 2000. Agronomy of fibre hemp (Cannabis sativa L.) in Europe. An International Journal Industrial Crops and Products, 11 , pp107 - 118. 